DOI: $10.2478 /$ pof-2018-0009

VOLUME 10, ISSUE 1, 2018

ISSN: $2036-5438$

\title{
The voting systems in the Council of the EU and the Bundesrat - What do they tell us about European Federalism?
}

by

Jacek Czaputowicz and Marcin Kleinowski*

Perspectives on Federalism, Vol. 10, issue 1, 2018 


\section{Abstract}

The Treaty of Lisbon introduced a new system of weighted votes in the Council, which radically departs from the principles on which the distribution of votes between the Member States of the EU was based for more than half a century. At the same time, the system of double majority is fundamentally different from the assumptions on which voting systems in federal states are based, including in the Bundesrat. Systems used in federal states are usually based on a compromise between the equality of states, and the equality of citizens. Consequently, in the Nice system, smaller Member States in the EU had relatively greater power compared to their populations than smaller federal units in the German Bundesrat. The results presented in this paper indicate that the Lisbon system of voting in the Council differs significantly from voting systems in federal states.

\section{Key-words}

Council of the European Union, Bundesrat, voting power, Nice voting system, double majority voting system 


\section{Introduction}

Is the European Union evolving towards a federal system? Evidence speaking for the European Union being similar to a federation includes: EU institutions taking over competences previously held by states; the principle of supremacy of European law and its direct effect in national law; and cooperation between federal institutions and the constituent units in executing various tasks. ${ }^{\mathrm{I}}$ What speaks against this thesis is: the lack of a European constitution; of the right to impose taxes; as well as the fact that states retain their membership in international organisations, such as the UN.

The EU's possible evolution towards a federation can also be examined from the perspective of changes in the voting system. We are interested in seeing whether the system of voting in the Council, introduced in the Treaty of Lisbon, brings the EU system closer to a federal system, or indeed departs further from it. The 1 April 2017 marked the end of a transitional period in which states could request voting in the Council on the Nice weighted voting system. Because states had to consider that any member of the Council could demand a vote count in accordance with the Nice system, they assessed the chances of creating a blocking coalition for this particular weighting method. For most countries, the formation of a blocking coalition was much easier under the provisions introduced by the Treaty of Nice. The end of the transitional period, and the unconditional application of the Lisbon double majority system will change the balance of power in the Council.

The double majority system introduces solutions that significantly differ not only from the Nice weighted voting system in the Council, but also from the way in which the weight of votes of constituent states is usually established in federal states. A voting system in which the size of the population is reflected proportionally constitutes a departure from the experience of federal states. Of course, the European Union (EU) is not a federation, although some researchers identify certain similarities. The EU political system is not classically divided into the executive, legislative and judiciary branch. In particular, the Council and European Commission both perform executive and legislative functions (Conway 2011; Ziller 2008; Lenaerts 1991). On the other hand, the role attributed to the Council of the EU is by some scholars seen as evolving towards that of a second chamber of parliament (Burgess 2000; Fabbrini 2012: 29). 
Specifically, the European Union is compared to Germany, which has two parallel levels of governance: the national (federal) level and the level of constituent states, making law in different policy areas and jointly governing the country (von Dosenrode 2007). The German equivalent of the word foedus is Bund. Germany's system is that of 'cooperative federalism', where sovereignty is shared and central authorities and constituent elements cooperate, working jointly in the same areas. Law making is a competence of the central authorities, while its implementation is the task of the constituent units. This differs from dual federalism, as seen in the United States, where the exclusive competences of the federal centre and the constituent units are set forth in the constitution and where the two levels act independently of each other.

The article compares the double majority voting system in the Council with the Nice system and the method of weighted votes in the German Bundesrat. The aim was to find out how these solutions affect the indirect voting power of the inhabitants of EU Member States and residents of the Federal Republic of Germany.

The first part of the paper will discuss the principles of decision-making in the Bundesrat. A simulation will show how the voting power of the various German constituent states, or Länder, would change if the Bundesrat were to employ a double majority system analogous to the one employed on the EU level. The second part will analyse the voting system that functioned in the European Union under the Nice system. The third part will be dedicated to analysing the double majority system that has been used since the entry into force of the Treaty of Lisbon. The article ends with conclusions.

The analysis is founded on the assumption that both the Bundesrat and the Council of the EU represent a two-tier decision-making system, in which the indirect power of each citizen's vote is equal to the product of the direct power of the citizen's vote in his/her voting constituency and the power of the vote of his/her representative in the council concerned. Every citizen belongs to a single voting constituency and independently expresses his/her own opinion on the initiative discussed in the council as if in an opinion poll in which he/she has a single vote and can only vote 'for' or 'against' the initiative in question. The distribution of citizens among the individual voting constituencies is random in terms of their views on the issues that can be decided by the council. The constituency representative votes 'for' or 'against' the initiative depending on what the majority of the citizens in the given constituency have chosen. Representatives in the council vote 
independently of each other, and how they vote is only determined by the results of the polls in the individual constituencies (Felsenthal and Machover 1998: 65-68).

The influence that each citizen has on the outcome of the voting process in the council will be equal when the power of the vote of a given constituency is proportional to the square root of its population (Felsenthal and Machover 1998: 63-78; Kirsch 2007; Penrose 1946). The square-root system is based on the principle of representativity, which means that every citizen, regardless of which Member State he/she is from, has the same voting power. In academic literature this system is considered fair (Scientist for a Democratic Europe 2004; Baldwin and Widgrén 2004; Felsenthal and Machover, 2004; Plechanovová 2004).

It could be questioned whether the application of the square root of the population, in counting the indirect power of every citizen's vote in a council, is a proper solution. When there is a strong correlation of citizens' preferences in individual constituencies and at the same time clear polarisation in their preferences between constituencies, the method could lead to 'dictatorship' of the minority (Felsenthal and Machover, 1998: 71).

We could therefore arrive at the conclusion that in a situation when the communities of various constituencies are homogeneous in terms of preference, with polarisation of preferences between communities, the voting power of the constituencies in the council should be proportional to their population. Consequently, a system in which the voting power of a given constituency in a council is proportional to its population can be deemed more appropriate because it reflects lasting differences in preferences between the individual constituencies. When the distribution of citizens between individual voting constituencies is random, as regards the views on the issues that could be decided on by the council, the voting power of their representatives in the joint decision-making body should be proportional to the square root of the population of these constituencies (Kirsch 2007: 357-380; Felsenthal and Machover 1998: 68-72).

Both for the Bundesrat and the Council of the EU, it seems more justified to assume that there is no significant correlation of citizen preferences in individual constituencies (German constituent states, EU Member States) and to consider the square-root system. One should agree with Kirsch (2007: 373) that designing a non-homogeneous voting system for a constitution or a treaty is not a simple task, even if we know the correlation structure of the countries in question. The correlation of preferences of citizens in 
particular constituencies varies depending on the issue being considered, and changes over time, while the constitutional voting system is generally expected to be applicable for a long time. Therefore, it seems reasonable to assume that there is no correlation between individual voters, even though it is an idealistic assumption. In order to determine the voting power of each player, we have used the Normalized Banzhaf Index (Banzhaf 1965).

The usefulness of voting power analyses has come under question from proponents of the non-cooperative approach. Albert $(2003,2004)$ denies the usefulness of voting games in the study of social and political realities because, in his view, they do not make it possible to gain empirical knowledge and, therefore, do not have any cognitive or prospective value. Garret and Tsebelis (1999a, b) criticise the application of power index approaches to the EU because they ignore the preferences of actors, the institutional rules that govern legislative processes, and the functioning of institutions other than the voting body which is the subject of an analysis. According to Barry (1980), as a result of ignoring the preferences of actors in voting games, they do not measure power, but luck - understood as a chance of finding oneself in a situation in which most of the other co-decision makers will have the same or similar preferences.

The use of the Normalised Banzhaf Index in the present study is not intended to assess the ability of members of a given voting body to influence the outcome of a decisionmaking process; it may not be reduced exclusively to voting power, as Garret and Tsebelis (1999a, b) rightly point out. The Normalized Banzhaf Index was used as a tool for comparing voting rules. As a consequence, we model the voting system as an "abstract shell" (Linder 2008: 593), ignoring all information apart from the voting rule itself inter alia the preferences of actors, other institutional rules in the legislative process, or political culture.

\section{The voting system in the German Bundesrat}

Germany is a federal state composed of 16 constituent states, the Länder. The Bundesrat is the organ of the Federation which ensures that the constituent states participate in the adoption of laws and in federal administration. The Bundesrat is tasked with representing the interests of the constituent states and protecting them from excessive intervention of federal authorities (Foster and Sule 2010: 207-210; Roberts 2009: 100-107). 
The members of the Bundesrat (69 in total) are delegated by the governments of the constituent states. The German constitution specifies the minimum and maximum number of votes that the Länder may have - from three for the least populous to six for the most populous. Resolutions are adopted by majority vote. Voting takes place in accordance with the guidelines provided by the governments of the individual Länder, and the position is agreed upon before the Bundesrat meeting. An imperative nature of the mandate requires that all delegates from a given constituent state vote the same, otherwise the vote of the entire delegation is considered void (Schmidt 2016: 285-293; Rudzio 2015: 288-289; Gunlicks 2013: 343-346). This means that the vote of a state is indivisible.

The number of votes in the Bundesrat is therefore not directly proportional to the population. Democratic legitimacy does not stem from the direct equality of citizens guaranteed by the voting system. Less populous constituent states have a stronger vote than that which would arise from their population. The least populated ones have three votes, the middle-sized ones have four, except for one which has five, and the most populous ones have six votes. Bremen, which has 660000 inhabitants, has three votes, as does Hamburg, which has two and a half times more inhabitants. Lower Saxony, with 8 million inhabitants, has six votes, the same number as North Rhine-Westphalia, which has more than two times as many inhabitants.

The table presented below (Table 1) shows the number of votes of each constituent state in the Bundesrat, the share of each constituent state in the total number of votes, the population, and the share in the total population.

We can clearly see that for the states that have six votes, the greater the population the greater the underestimation of the weight of their vote, calculated as the ratio of the share in total population to the share in the total number of votes. For example, for Lower Saxony the ratio is 1.11 , and for North Rhine-Westphalia it is 2.5 (vote weight is 2.5 times lower than the share in total population). The opposite is true for the group of Länder that have three or four votes in the Bundesrat. There is a distinct regularity here that the lower the population the greater the overrepresentation of a Land in the number of weighted votes. For Bremen, it is more than five times greater than its share in total population. 
Table 1: population of the German Länder and the number of votes in the Bundesrat

\begin{tabular}{|l|c|c|c|c|}
\hline \multicolumn{1}{|c|}{ Land } & $\begin{array}{c}\text { Number of } \\
\text { votes in the } \\
\text { Bundesrat }\end{array}$ & $\begin{array}{c}\text { Share in the total } \\
\text { number of votes }\end{array}$ & Population & $\begin{array}{c}\text { Share in total } \\
\text { population }\end{array}$ \\
\hline North Rhine-Westphalia & 6 & 0.0870 & 17638098 & 0.2172 \\
Bavaria & 6 & 0.0870 & 12691568 & 0.1563 \\
Baden-Württemberg & 6 & 0.0870 & 10716644 & 0.1320 \\
Lower Saxony & 6 & 0.0870 & 7826739 & 0.0964 \\
Hesse & 5 & 0.0725 & 6093888 & 0.0751 \\
Saxony & 4 & 0.0580 & 4055274 & 0.0499 \\
Rhineland-Palatinate & 4 & 0.0580 & 4011582 & 0.0494 \\
Berlin & 4 & 0.0580 & 3469849 & 0.0427 \\
Schleswig-Holstein & 4 & 0.0580 & 2830864 & 0.0349 \\
Brandenburg & 4 & 0.0580 & 2457872 & 0.0303 \\
Saxony-Anhalt & 4 & 0.0580 & 2235548 & 0.0275 \\
Thuringia & 4 & 0.0580 & 2156759 & 0.0266 \\
Hamburg & 3 & 0.0435 & 1762791 & 0.0217 \\
Mecklenburg-Vorpommern & 3 & 0.0435 & 1599138 & 0.0197 \\
Saarland & 3 & 0.0435 & 989035 & 0.0122 \\
Bremen & 69 & 0.0435 & 661888 & 0.0082 \\
\hline Total & 3 & & 81197537 & \\
\hline Source: Own & 3 & & & \\
\hline
\end{tabular}

Source: Own calculations. The population of the Länder as on 31 December 2014 on the basis of Destatis data, http://www.statistik-portal.de/Statistik-Portal/en/en_jb01_jahrtab1.asp (accessed on 8 April 2016).

A more comprehensive analysis can be conducted using the Normalized Banzhaf Index (NBI), which illustrates the share of a given player (e.g. a constituent state) in the total number of swing votes of all states (Banzhaf 1965; Felsenthal and Machover 1998: 32-51). It shows the probability of a given constituent state becoming a pivotal player, in other words, of a situation when the decision whether a proposal will be passed or rejected by the Bundesrat will be entirely up to this state. A constituent state has a pivotal position when its withdrawal from the winning coalition means that the coalition is no longer winning because the sum of votes of its members is lower than the voting threshold.

To calculate the NBI, it is first necessary to identify the pivotal players in all the possible winning coalitions and then calculate the total number of situations for each player in which it would be the swing member of a coalition. The NBI for each player is determined as the ratio of its swings to the total number of swings. Table 2 presents a 
sample game with a voting threshold of $\mathrm{q}=6$. The total number of swings of all players is five ( $a=3, b=1, c=1$, respectively). As a result, the NBI takes the following values: $a=0.6$; $\mathrm{b}=0.2 ; \mathrm{c}=0.2$.

Table 2: coalitions in a game with a threshold of $\mathrm{Q}=6$ and players weights $\mathrm{A}=5, \mathrm{~B}=4 ; \mathrm{C}=1$

\begin{tabular}{|c|c|c|c|}
\hline Coalition & $\begin{array}{c}\text { Coalition } \\
\text { weight }\end{array}$ & $\begin{array}{c}\text { Coalition } \\
\text { type }\end{array}$ & $\begin{array}{c}\text { Pivotal } \\
\text { players }\end{array}$ \\
\hline $\mathrm{a}$ & 5 & $\mathrm{~B}$ & - \\
\hline $\mathrm{ab}$ & 9 & $\mathrm{~W}$ & $\mathrm{a}, \mathrm{b}$ \\
\hline $\mathrm{ac}$ & 6 & $\mathrm{~W}$ & $\mathrm{a}, \mathrm{c}$ \\
\hline $\mathrm{abc}$ & 10 & $\mathrm{~W}$ & $\mathrm{a}$ \\
\hline $\mathrm{bc}$ & 5 & $\mathrm{~B}$ & - \\
\hline $\mathrm{b}$ & 4 & $\mathrm{~L}$ & - \\
\hline $\mathrm{c}$ & 1 & $\mathrm{~L}$ & - \\
\hline$\varnothing$ & 0 & $\mathrm{~L}$ & - \\
\hline
\end{tabular}

W- Winning L- Losing B- Blocking

The NBI indicates that the vote weighting system in the Bundesrat gives preferential treatment to the Länder with the lowest populations, and is disadvantageous to those with the largest populations. In the German system, voting power shifts from the three most populous constituent states, mainly to those with populations lower than 3 million, especially Saarland and Bremen. This is clearly visible in the values of the ratio of voting power to the square root of population. The ratio of voting power to population was calculated using the $(\eta S) /(\mathrm{H} s)$ formula (Felsenthal and Machover 1998: 166), where:

$\eta$ - the number of swings of a given player (country, Land) in a given voting system;

$\mathrm{H}$-the sum of swings of all players (countries, Länder);

$s$ - the square root of the player's population (countries, Länder);

$\mathrm{S}$ - the sum of square roots of the populations of all players (countries, Länder) in the council.

When the ratio equals 1 , it means that the voting power of the Land is proportional to the square root of its population. When it is less than 1 , then the voting power of the given Land is smaller than its population would suggest. When it is greater than 1, the voting power is greater than the population of the Land would suggest. Thus, the ratio describes the disproportion between the player's voting power and its participation in the total population of all the constituent states. 
As shown by the data presented in Table 3, the voting power of the five most populous constituent states is underestimated to various extents, while the voting power of eleven states is overestimated compared to their population. The state that is most strongly affected by underestimation is the most populous one-North Rhine-Westphalia, and the one most strongly affected by overestimation is the least populous one - Bremen.

Table 3: analysis of the voting system in the Bundesrat

\begin{tabular}{|c|c|c|c|c|c|c|c|c|}
\hline Land & $\begin{array}{c}\text { Number } \\
\text { of votes in } \\
\text { the } \\
\text { Bundesrat }\end{array}$ & $\begin{array}{l}\text { Share in } \\
\text { the total } \\
\text { number } \\
\text { of votes }\end{array}$ & Population & $\begin{array}{c}\text { Share in } \\
\text { total } \\
\text { population }\end{array}$ & $\begin{array}{l}\text { Number of } \\
\text { swings }(\eta)\end{array}$ & NBI & $\begin{array}{l}\text { Ratio of } \\
\text { voting } \\
\text { power to } \\
\text { the square } \\
\text { root of } \\
\text { population } \\
\text { (A) }\end{array}$ & A-1 \\
\hline North Rhine-Westphalia & 6 & 0.087 & 17638098 & 0.2172 & 8974 & 0.0882 & 0.689 & -0.311 \\
\hline Bavaria & 6 & 0.087 & 12691568 & 0.1563 & 8974 & 0.0882 & 0.812 & -0.188 \\
\hline Baden-Württemberg & 6 & 0.087 & 10716644 & 0.132 & 8974 & 0.0882 & 0.884 & -0.116 \\
\hline Lower Saxony & 6 & 0.087 & 7826739 & 0.0964 & 8974 & 0.0882 & 1.034 & 0.034 \\
\hline Hesse & 5 & 0.0725 & 6093888 & 0.0751 & 7630 & 0.075 & 0.997 & -0.003 \\
\hline Saxony & 4 & 0.058 & 4055274 & 0.0499 & 5830 & 0.0573 & 0.934 & -0.066 \\
\hline Rhineland-Palatinate & 4 & 0.058 & 4011582 & 0.0494 & 5830 & 0.0573 & 0.939 & -0.061 \\
\hline Berlin & 4 & 0.058 & 3469849 & 0.0427 & 5830 & 0.0573 & 1.009 & 0.009 \\
\hline Schleswig-Holstein & 4 & 0.058 & 2830864 & 0.0349 & 5830 & 0.0573 & 1.117 & 0.117 \\
\hline Brandenburg & 4 & 0.058 & 2457872 & 0.0303 & 5830 & 0.0573 & 1.199 & 0.199 \\
\hline Saxony-Anhalt & 4 & 0.058 & 2235548 & 0.0275 & 5830 & 0.0573 & 1.257 & 0.257 \\
\hline Thuringia & 4 & 0.058 & 2156759 & 0.0266 & 5830 & 0.0573 & 1.280 & 0.280 \\
\hline Hamburg & 3 & 0.0435 & 1762791 & 0.0217 & 4342 & 0.0427 & 1.055 & 0.055 \\
\hline Mecklenburg-Vorpommern & 3 & 0.0435 & 1599138 & 0.0197 & 4342 & 0.0427 & 1.107 & 0.107 \\
\hline Saarland & 3 & 0.0435 & 989035 & 0.0122 & 4342 & 0.0427 & 1.408 & 0.408 \\
\hline Bremen & 3 & 0.0435 & 661888 & 0.0082 & 4342 & 0.0427 & 1.721 & 0.721 \\
\hline Total & 69 & & 81197537 & & 101704 & 1 & & \\
\hline
\end{tabular}

Source: Own calculations. The population of the Länder as on 31 December 2014 on the basis of Destatis data, http://www.statistik-portal.de/Statistik-Portal/en/en jb01 jahrtab1.asp (accessed on 8 April 2016).

The German system combines egalitarian legitimacy of the Bundesrat and federal legitimacy of the Bundesrat. The voting system is therefore not based on purely egalitarian, democratic legitimacy. The former President of the European Parliament, Martin Schultz, highlighted this by saying that in the German federal system the governments of the 16 states send their representatives to the second chamber, the Bundesrat, where North Rhine-Westphalia, with its 18 million inhabitants, has six votes, just as BadenWürttemberg, although the latter is inhabited by only 11 million people; Bremen, in turn, 
has three votes in the Bundesrat, although it only has 600000 inhabitants, which means that only 200000 is enough to get a single vote in the Bundesrat, while in North RhineWestphalia three million inhabitants are needed for a single vote (Schulz 2014: 50-51). If we were to understand a democratic system as strict majority rule, then we should be asking ourselves the question whether Germany meets the criteria of a democratic state (Schönberger 2009: 1212). Indeed, the German system may be criticised for the overpowering role of ideological divisions within the Bundesrat and the potential of obstruction.

We can also analyse how the power of the individual Länder would change if the double majority voting system, analogous to the one established under the Treaty of Lisbon, were introduced in the Bundesrat. We have performed a simulation assuming that passing decisions in this institution would require the support of 55 per cent of the constituent states representing at least 65 per cent of the population of Germany. The results are presented in Table 4 and in Graph 1.

Graph 1: change of the voting power of the German Länder (measured in NBI) when applying the Lisbon system of double majority vote weighting in the Bundesrat

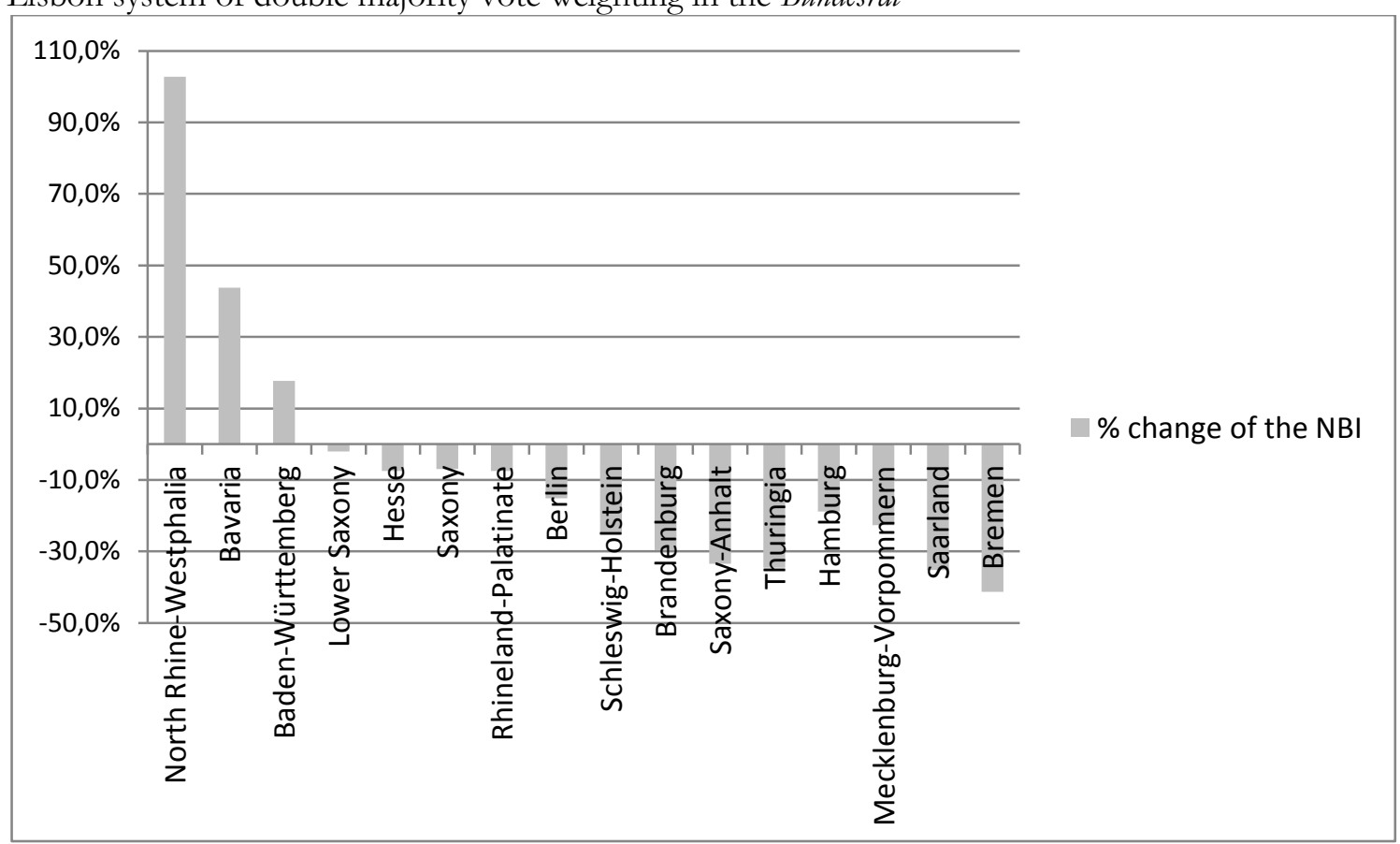

Source: Own calculations. 
Table 4: the voting power of the German Länder when applying the double majority vote weighting system in the Bundesrat

\begin{tabular}{|c|c|c|c|c|c|c|c|}
\hline Land & Population & $\begin{array}{l}\text { Share in } \\
\text { the total } \\
\text { number } \\
\text { of votes }\end{array}$ & $\begin{array}{c}\text { Normalized } \\
\text { Banzhaf } \\
\text { Index (A) }\end{array}$ & $\begin{array}{l}\text { Normalized } \\
\text { Banzhaf } \\
\text { Index in the } \\
\text { Bundesrat } \\
\text { system (B) }\end{array}$ & $\begin{array}{c}\text { Value } \\
\text { change of } \\
\text { the } \\
\text { Normalized } \\
\text { Banzhaf } \\
\text { Index (A-B) }\end{array}$ & $\begin{array}{l}\text { Ratio of } \\
\text { voting } \\
\text { power to } \\
\text { the square } \\
\text { root of } \\
\text { population } \\
\text { (C) }\end{array}$ & C-1 \\
\hline North Rhine-Westphalia & 17638098 & 0.2172 & 0.1789 & 0.0882 & 0.0906 & 1.397 & 0.397 \\
\hline Bavaria & 12691568 & 0.1563 & 0.1269 & 0.0882 & 0.0386 & 1.168 & 0.168 \\
\hline Baden-Württemberg & 10716644 & 0.1320 & 0.1038 & 0.0882 & 0.0156 & 1.040 & 0.040 \\
\hline Lower Saxony & 7826739 & 0.0964 & 0.0864 & 0.0882 & -0.0018 & 1.013 & 0.013 \\
\hline Hesse & 6093888 & 0.0751 & 0.0694 & 0.0750 & -0.0056 & 0.922 & -0.078 \\
\hline Saxony & 4055274 & 0.0499 & 0.0534 & 0.0573 & -0.0040 & 0.869 & -0.131 \\
\hline Rhineland-Palatinate & 4011582 & 0.0494 & 0.0530 & 0.0573 & -0.0043 & 0.868 & -0.132 \\
\hline Berlin & 3469849 & 0.0427 & 0.0486 & 0.0573 & -0.0087 & 0.856 & -0.144 \\
\hline Schleswig-Holstein & 2830864 & 0.0349 & 0.0432 & 0.0573 & -0.0141 & 0.842 & -0.158 \\
\hline Brandenburg & 2457872 & 0.0303 & 0.0403 & 0.0573 & -0.0170 & 0.844 & -0.156 \\
\hline Saxony-Anhalt & 2235548 & 0.0275 & 0.0381 & 0.0573 & -0.0192 & 0.836 & -0.164 \\
\hline Thuringia & 2156759 & 0.0266 & 0.0375 & 0.0573 & -0.0198 & 0.838 & -0.162 \\
\hline Hamburg & 1762791 & 0.0217 & 0.0347 & 0.0427 & -0.0080 & 0.856 & -0.144 \\
\hline Mecklenburg-Vorpommern & 1599138 & 0.0197 & 0.0330 & 0.0427 & -0.0097 & 0.856 & -0.144 \\
\hline Saarland & 989035 & 0.0122 & 0.0277 & 0.0427 & -0.0150 & 0.913 & -0.087 \\
\hline Bremen & 661888 & 0.0082 & 0.0251 & 0.0427 & -0.0176 & 1.011 & 0.011 \\
\hline Total & 81197537 & & 1 & 1 & & & \\
\hline
\end{tabular}

Source: Own calculations. The population of the Länder as on 31 December 2014 on the basis of Destatis data, http://www.statistik-portal.de/Statistik-Portal/en/en jb01 jahrtab1.asp (accessed on 8 April 2016).

Unsurprisingly, in the situation in question there is a considerable shift of voting power to the three least populous Länder at the expense of all the others. In the case of North Rhine-Westphalia, the NBI value increased by more than 100 per cent. In the case of Thuringia, Saarland and Bremen, the NBI value fell by more than 30 per cent. The double majority system functioning in the European Union would probably be deemed unnatural and unjust in the German political system. 
We shall begin the analysis of the European Union from the system referred to as the Nice system, which was functioning before the reform implemented by the Treaty of Lisbon.

\section{The Nice voting system}

The voting system in the Council of the EU, set out in the Treaty of Nice of 2001, was based on voting principles introduced by the founders of the European Communities, essentially analogous to those employed in the Bundesrat. In this system, vote weight was only related to population to a certain extent. For a decision to be passed in the Council of the EU, on the initiative of the European Commission, it is necessary for two criteria to be met: the majority of members (at least 15 out of 28 states) and 260 out of 352 weighted votes, which is approximately 73.86 per cent of their total number. At the same time, every member of the Council of the EU may request verification of compliance with the optional criterion of a minimum 62 per cent majority of the total EU population (Protocol No 36, 2012, Article 3).

Given these prerequisites, the key goal was to achieve the threshold of weighted votes, as then it was rather unlikely that the other conditions would not be met. In this system, there are 5,032,111 possible winning coalitions. If only weighted votes were considered in decision-making, the number of winning coalitions would be 5,032,534. This means that among all the coalitions that meet the criterion of weighted votes, only 423 do not meet the majority of states and 62 per cent of the population requirement. ${ }^{\text {II }}$

Calculations analogous to those performed for the Bundesrat can also be performed for the Nice voting system. In this system, the difference between the least and most populous countries is similar to that between the least and most populous German constituent states. The columns of Table 5 present this analysis showing the number of votes held by the individual countries, the share of each country in the total number of votes, the population and the share of each country in total population.

As we can see, in this case the underestimation of the voting power of Germany compared to its population is less than the underestimation of the voting power of North Rhine-Westphalia, and similar to that of Bavaria. However, the overestimation of the 
voting power of the least populous countries - Cyprus, Malta and Luxembourg - is greater than the overestimation of the voting power of Bremen. Considering the fact that the number of EU Member States (28) is much bigger than the number of German constituent states (16) and that there are much greater differences in population size between the members of the Council of the EU than between the members of the Bundesrat,

Table 5: analysis of the Nice voting system in the Council of the EU

\begin{tabular}{|c|c|c|c|c|c|c|c|c|}
\hline EU Member State & Population & $\begin{array}{c}\text { Share in } \\
\text { total } \\
\text { population }\end{array}$ & $\begin{array}{c}\text { Number } \\
\text { of } \\
\text { weighted } \\
\text { votes }\end{array}$ & $\begin{array}{c}\text { Share in } \\
\text { total } \\
\text { number } \\
\text { of } \\
\text { weighted } \\
\text { votes }\end{array}$ & $\begin{array}{c}\text { Number } \\
\text { of swings } \\
(\eta)\end{array}$ & NBI & $\begin{array}{l}\text { Ratio of } \\
\text { voting } \\
\text { power to the } \\
\text { square root } \\
\text { of } \\
\text { population } \\
\text { (A) }\end{array}$ & A-1 \\
\hline Germany & 81089331 & 0.1593 & 29 & 0.0824 & 4079453 & 0.0759 & 0.8338 & -0.1662 \\
\hline France & 66352469 & 0.1304 & 29 & 0.0824 & 4079413 & 0.0759 & 0.9218 & -0.0782 \\
\hline United Kingdom & 64767115 & 0.1273 & 29 & 0.0824 & 4079403 & 0.0759 & 0.9330 & -0.0670 \\
\hline Italy & 61438480 & 0.1207 & 29 & 0.0824 & 4079385 & 0.0759 & 0.9579 & -0.0421 \\
\hline Spain & 46439864 & 0.0912 & 27 & 0.0767 & 3893839 & 0.0725 & 1.0517 & 0.0517 \\
\hline Poland & 38005614 & 0.0747 & 27 & 0.0767 & 3893769 & 0.0725 & 1.1625 & 0.1625 \\
\hline Romania & 19861408 & 0.0390 & 14 & 0.0398 & 2242131 & 0.0417 & 0.9260 & -0.0740 \\
\hline Netherlands & 17155169 & 0.0337 & 13 & 0.0369 & 2096013 & 0.0390 & 0.9314 & -0.0686 \\
\hline Belgium & 11258434 & 0.0221 & 12 & 0.0341 & 1938141 & 0.0361 & 1.0632 & 0.0632 \\
\hline Greece & 10846979 & 0.0213 & 12 & 0.0341 & 1938141 & 0.0361 & 1.0831 & 0.0831 \\
\hline Czech Republic & 10419743 & 0.0205 & 12 & 0.0341 & 1938141 & 0.0361 & 1.1051 & 0.1051 \\
\hline Portugal & 10374822 & 0.0204 & 12 & 0.0341 & 1938141 & 0.0361 & 1.1075 & 0.1075 \\
\hline Hungary & 9855571 & 0.0194 & 12 & 0.0341 & 1938141 & 0.0361 & 1.1363 & 0.1363 \\
\hline Sweden & 9790000 & 0.0192 & 10 & 0.0284 & 1629099 & 0.0303 & 0.9583 & -0.0417 \\
\hline Austria & 8581500 & 0.0169 & 10 & 0.0284 & 1629099 & 0.0303 & 1.0236 & 0.0236 \\
\hline Bulgaria & 7202198 & 0.0142 & 10 & 0.0284 & 1629099 & 0.0303 & 1.1173 & 0.1173 \\
\hline Denmark & 5653357 & 0.0111 & 7 & 0.0199 & 1149831 & 0.0214 & 0.8901 & -0.1099 \\
\hline Finland & 5471753 & 0.0108 & 7 & 0.0199 & 1149831 & 0.0214 & 0.9047 & -0.0953 \\
\hline Slovakia & 5403134 & 0.0106 & 7 & 0.0199 & 1149831 & 0.0214 & 0.9105 & -0.0895 \\
\hline Ireland & 4625885 & 0.0091 & 7 & 0.0199 & 1149831 & 0.0214 & 0.9840 & -0.0160 \\
\hline Croatia & 4225316 & 0.0083 & 7 & 0.0199 & 1149829 & 0.0214 & 1.0296 & 0.0296 \\
\hline Lithuania & 2921262 & 0.0057 & 7 & 0.0199 & 1149829 & 0.0214 & 1.2382 & 0.2382 \\
\hline Slovenia & 2062874 & 0.0041 & 4 & 0.0114 & 659619 & 0.0123 & 0.8453 & -0.1547 \\
\hline Latvia & 1986096 & 0.0039 & 4 & 0.0114 & 659619 & 0.0123 & 0.8615 & -0.1385 \\
\hline Estonia & 1313271 & 0.0026 & 4 & 0.0114 & 659619 & 0.0123 & 1.0594 & 0.0594 \\
\hline Cyprus & 847008 & 0.0017 & 4 & 0.0114 & 659617 & 0.0123 & 1.3192 & 0.3192 \\
\hline Luxembourg & 562958 & 0.0011 & 4 & 0.0114 & 659613 & 0.0123 & 1.6181 & 0.6181 \\
\hline Malta & 429344 & 0.0008 & 3 & 0.0085 & 497259 & 0.0093 & 1.3968 & 0.3968 \\
\hline Total & 508940955 & & 352 & & 53715736 & 1 & & \\
\hline
\end{tabular}

Source: Own calculations. 
which to a certain extent explains the slightly bigger range, we can conclude that the Bundesrat system and the Nice system are strikingly similar in terms of the privilege they give to inhabitants of smaller constituents, be it the German Länder or the EU Member States, in terms of voting power.

\section{The Lisbon double majority voting system}

Pursuant to the voting rules introduced by the Treaty of Lisbon, which have been in force since 1 November 2014, vote weight is directly proportional to population size. For a decision to be passed, on the initiative of the European Commission or the High Representative of the Union for Foreign Affairs and Security Policy, a double majority is required: of 55 per cent of Member States and 65 per cent of EU's population. An additional provision requires that any blocking minority must comprise a minimum number of members of the Council, representing more than 35 per cent of the population of the participating countries, plus one additional member - in the full make-up of the Council, it must be at least four states. ${ }^{\mathrm{III}}$ Just as it is the case in the Bundesrat, the vote of each country in the Council is cumulated and indivisible, which means that its position always represents the entire population of the country. ${ }^{\text {IV }}$ The transitional period, in force until 31 March 2017, provided for an option to apply for a voting pursuant to the old vote weighting system. The calculation of voting power in the double majority system has been conducted in the same manner as the calculations for the Bundesrat and the Nice system; the effects are presented in Table 6.

Some researchers believe that in this system the vote of an inhabitant of a less populous country is stronger than a vote of an inhabitant of a more populous country (Neyer, 2010: 171). In fact, however, the NBI and the share of individual EU Member States in the total population are clearly different. This shows that the criterion of the majority of states in the double majority system influences the voting power of the players. Compared to the Nice solution, this system gives preference to countries that base their voting power mainly on one of the two vote weighting criteria. 
Table 6: analysis of the vote weighting system in the Council of the EU (the double majority system)

\begin{tabular}{|c|c|c|c|c|c|c|}
\hline EU Member States & Population & $\begin{array}{c}\text { Share in } \\
\text { total } \\
\text { population }\end{array}$ & $\begin{array}{l}\text { Number of } \\
\text { swings ( } \eta\end{array}$ & $\begin{array}{l}\text { Normalized } \\
\text { Banzhaf } \\
\text { Index }\end{array}$ & $\begin{array}{l}\text { Ratio of voting } \\
\text { power to the } \\
\text { square root of } \\
\text { population (A) }\end{array}$ & A-1 \\
\hline Germany & 81089331 & 0.1593 & 22596065 & 0.1019 & 1.1193 & 0.1193 \\
\hline France & 66352469 & 0.1304 & 18721721 & 0.0845 & 1.0252 & 0.0252 \\
\hline United Kingdom & 64767115 & 0.1273 & 18325465 & 0.0827 & 1.0157 & 0.0157 \\
\hline Italy & 61438480 & 0.1207 & 17540493 & 0.0791 & 0.9982 & -0.0018 \\
\hline Spain & 46439864 & 0.0912 & 13745229 & 0.0620 & 0.8997 & -0.1003 \\
\hline Poland & 38005614 & 0.0747 & 11243003 & 0.0507 & 0.8135 & -0.1865 \\
\hline Romania & 19861408 & 0.0390 & 8382835 & 0.0378 & 0.8391 & -0.1609 \\
\hline Netherlands & 17155169 & 0.0337 & 7752715 & 0.0350 & 0.8349 & -0.1651 \\
\hline Belgium & 11258434 & 0.0221 & 6421841 & 0.0290 & 0.8537 & -0.1463 \\
\hline Greece & 10846979 & 0.0213 & 6329559 & 0.0286 & 0.8573 & -0.1427 \\
\hline Czech Republic & 10419743 & 0.0205 & 6233077 & 0.0281 & 0.8613 & -0.1387 \\
\hline Portugal & 10374822 & 0.0204 & 6222927 & 0.0281 & 0.8618 & -0.1382 \\
\hline Hungary & 9855571 & 0.0194 & 6106315 & 0.0276 & 0.8676 & -0.1324 \\
\hline Sweden & 9790000 & 0.0192 & 6091487 & 0.0275 & 0.8684 & -0.1316 \\
\hline Austria & 8581500 & 0.0169 & 5819419 & 0.0263 & 0.8861 & -0.1139 \\
\hline Bulgaria & 7202198 & 0.0142 & 5509353 & 0.0249 & 0.9157 & -0.0843 \\
\hline Denmark & 5653357 & 0.0111 & 5159793 & 0.0233 & 0.9680 & -0.0320 \\
\hline Finland & 5471753 & 0.0108 & 5118931 & 0.0231 & 0.9762 & -0.0238 \\
\hline Slovakia & 5403134 & 0.0106 & 5103491 & 0.0230 & 0.9794 & -0.0206 \\
\hline Ireland & 4625885 & 0.0091 & 4928019 & 0.0222 & 1.0221 & 0.0221 \\
\hline Croatia & 4225316 & 0.0083 & 4837807 & 0.0218 & 1.0498 & 0.0498 \\
\hline Lithuania & 2921262 & 0.0057 & 4542713 & 0.0205 & 1.1856 & 0.1856 \\
\hline Slovenia & 2062874 & 0.0041 & 4347777 & 0.0196 & 1.3503 & 0.3503 \\
\hline Latvia & 1986096 & 0.0039 & 4330409 & 0.0195 & 1.3707 & 0.3707 \\
\hline Estonia & 1313271 & 0.0026 & 4177525 & 0.0188 & 1.6261 & 0.6261 \\
\hline Cyprus & 847008 & 0.0017 & 4071339 & 0.0184 & 1.9733 & 0.9733 \\
\hline Luxembourg & 562958 & 0.0011 & 4006721 & 0.0181 & 2.3821 & 1.3821 \\
\hline Malta & 429344 & 0.0008 & 3976187 & 0.0179 & 2.7069 & 1.7069 \\
\hline Total & 508940955 & & 221642216 & 1 & & \\
\hline
\end{tabular}

Source: Own calculations. Population data on the basis of Council Decision (EU, Euratom) 2015/2393 of 8 December 2015 amending the Council's Rules of Procedure, "Official Journal of the European Union" 
L332, 18.12.2015.

As a result, the system favours countries with the largest populations, especially Germany, and the six countries with the lowest populations, at the expense of the other Member States. In the case of the four smallest states, increased formal voting power results from the need to achieve a 55 per cent majority of Member States to adopt a decision. The scale of the shift of formal vote power between the members of the Council following the replacement of the Nice system by the double majority system is presented in Graph 2.

Graph 2: change of the voting power of the members of the Council (measured in NBI) due to the replacement of the Nice system with the double majority system

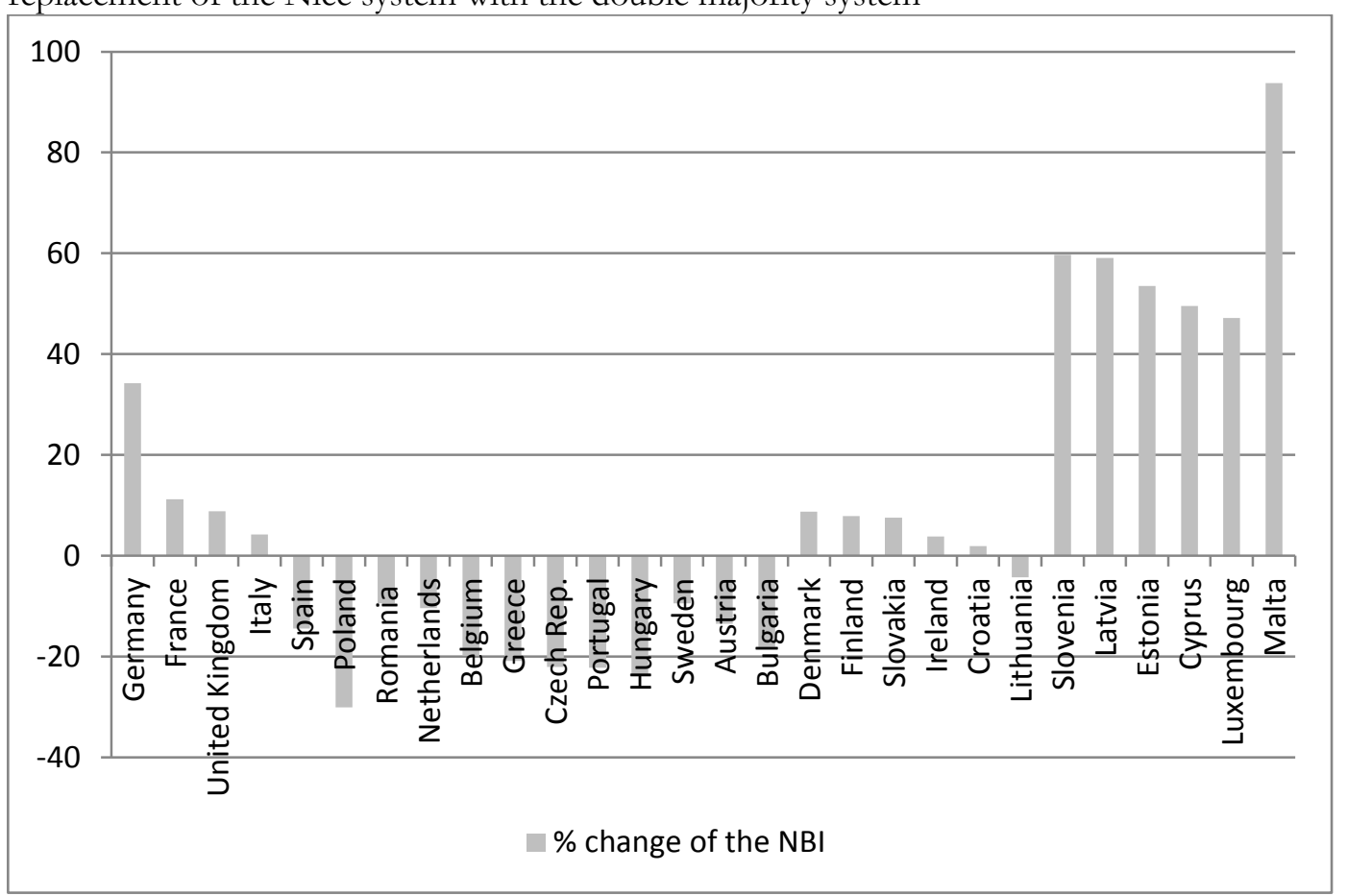

Source: Own calculations.

It should be stressed that we are using the category of inhabitants (or population), not citizens, because pursuant to current laws, the weighting method takes into account the usually resident population of a Member State at the reference time: the citizens of this Member State as well as citizens of other Member States and people from outside the European Union (Regulation (EU) No 1260/2013, 2013, Article 4(1)). This system favours the countries of the 'old Union', in which the number of immigrants is relatively higher: for 
example, in Germany it is almost 9 per cent, in Spain more than 10 per cent, while in Poland it is only 0.27 per cent of the population. ${ }^{\mathrm{V}}$

As shown in Table 7, the shift of formal voting power between the players - compared to its distribution proportionally to the square root of the population - is considerably greater in the Bundesrat system and double majority than in the Nice system.

Table 7: differences in the voting power of players in the Bundesrat, Nice and double majority systems in relation to voting systems in which the power of players would be proportional to the square root of the number of represented inhabitants

\begin{tabular}{|l|c|c|}
\cline { 2 - 3 } \multicolumn{1}{|c|}{ Land } & Bundesrat system & $\begin{array}{c}\text { Bundesrat } \\
\text { according to the } \\
\text { double majority } \\
\text { system }\end{array}$ \\
\hline $\begin{array}{l}\text { Difference } \\
\text { between NBI and }\end{array}$ & $\begin{array}{c}\text { NBI proportional } \\
\text { Detween NBI and } \\
\text { to the square root } \\
\text { of population } \\
\text { to the square root } \\
\text { of population }\end{array}$ \\
\hline Bavaria & -0.0398 & 0.0508 \\
Baden-Württemberg & -0.0204 & 0.0183 \\
Lower Saxony & -0.0116 & 0.0040 \\
Hesse & 0.0029 & 0.0011 \\
Saxony & -0.0002 & -0.0059 \\
Rhineland-Palatinate & -0.0041 & -0.0080 \\
Berlin & -0.0037 & -0.0081 \\
\hline Schleswig-Holstein & 0.0005 & -0.0082 \\
Brandenburg & 0.0060 & -0.0081 \\
Saxony-Anhalt & 0.0095 & -0.0075 \\
Thuringia & 0.0117 & -0.0075 \\
Hamburg & 0.0125 & -0.0073 \\
Mecklenburg- & 0.0022 & -0.0058 \\
Vorpommern & 0.0041 & -0.0055 \\
Saarland & 0.0124 & -0.0027 \\
Bremen & 0.0179 & 0.0003 \\
\hline Total shift of voting \\
power & 0.0799 & 0.0745 \\
\hline
\end{tabular}

\begin{tabular}{|c|c|c|}
\hline Nice system & $\begin{array}{l}\text { Double majority } \\
\text { system }\end{array}$ & \\
\hline $\begin{array}{c}\text { Difference } \\
\text { between NBI and } \\
\text { NBI proportional } \\
\text { to the square root } \\
\text { of population }\end{array}$ & $\begin{array}{c}\text { Difference } \\
\text { between NBI } \\
\text { and NBI } \\
\text { proportional to } \\
\text { the square root } \\
\text { of population }\end{array}$ & EU Member State \\
\hline-0.0151 & 0.0109 & Germany \\
\hline-0.0064 & 0.0021 & France \\
\hline-0.0055 & 0.0013 & United Kingdom \\
\hline-0.0033 & -0.0001 & Italy \\
\hline 0.0036 & -0.0069 & Spain \\
\hline 0.0101 & -0.0116 & Poland \\
\hline-0.0033 & -0.0073 & Romania \\
\hline-0.0029 & -0.0069 & Netherlands \\
\hline 0.0021 & -0.0050 & Belgium \\
\hline 0.0028 & -0.0048 & Greece \\
\hline 0.0034 & -0.0045 & Czech Republic \\
\hline 0.0035 & -0.0045 & Portugal \\
\hline 0.0043 & -0.0042 & Hungary \\
\hline-0.0013 & -0.0042 & Sweden \\
\hline 0.0007 & -0.0034 & Austria \\
\hline 0.0032 & -0.0023 & Bulgaria \\
\hline-0.0026 & -0.0008 & Denmark \\
\hline-0.0023 & -0.0006 & Finland \\
\hline-0.0021 & -0.0005 & Slovakia \\
\hline-0.0003 & 0.0005 & Ireland \\
\hline 0.0006 & 0.0010 & Croatia \\
\hline 0.0041 & 0.0032 & Lithuania \\
\hline-0.0022 & 0.0051 & Slovenia \\
\hline-0.0020 & 0.0053 & Latvia \\
\hline 0.0007 & 0.0073 & Estonia \\
\hline
\end{tabular}


Source: Own calculations.

\begin{tabular}{|l|l|l|}
\hline 0.0030 & 0.0091 & Cyprus \\
\hline 0.0047 & 0.0105 & Luxembourg \\
0.0026 & 0.0113 & Malta \\
\hline 0.0495 & 0.0674 & $\begin{array}{l}\text { Total shift of } \\
\text { voting power }\end{array}$ \\
\hline
\end{tabular}

In the case of the Bundesrat, however, more than half of this shift is generated by underestimating the voting power of North Rhine-Westphalia, which has a much larger population than the other German constituent states. The Bundesrat system and the Nice system particularly underestimate the voting power of the most populous players, while in the double majority system there is a relatively large shift of power towards Germany as well as Malta and Luxembourg.

When applying the double majority system to decision-making in the Bundesrat, there is a considerable shift of voting power towards the two most populous Länder, resulting in an overestimation of the voting powers of their inhabitants.

However, the influence of the most populous EU Member States on the decisionmaking process is much greater than what would result from their formal voting power.

It happens very often that the stance of these countries, or at least the majority of them, is what determines the framework within which it is possible to reach an agreement. In a vast majority of cases, decisions in the Council are made on the initiative of the European Commission - especially when they concern the adoption of legislation. Only in extremely rare cases does the 'Guardian of the Treaties' come up with an initiative that would not be backed by the majority of Member States. ${ }^{\text {VI }}$ This means that in practice a blocking minority has to be developed on the basis of the criterion of population.

Member States' voting power in the Council affects their positions in three ways: (1) by having an impact on their ability to force the adoption of decisions, (2) by having an impact on their ability to block decisions and (3) by having their position taken into account to a greater extent in the process of selection and aggregation of interests at the drafting stage, provided that they do not take extreme positions. These mechanisms would also work on the level of the federal state, and in the case of the Bundesrat it would increase the ability of the Länder that have relatively large populations to enforce and block decisions. 
Under the double majority system, when a decision in the Council of the EU is made by qualified majority on the initiative of the European Commission or the High Representative of the Union for Foreign Affairs and Security Policy, with 28 Member States of the European Union, the blocking minority requires at least four members of the Council, representing more than 35 per cent of the population of the Member States. ${ }^{\text {VII }}$ The six most populous countries (21.43 per cent of the Member States) account for more than 70.36 per cent of the population of the European Union, and the remaining 22 countries (78.57 per cent of the Member States) account for only 29.64 per cent.

Spain or Poland are unable to form a blocking coalition of a maximum of 12 members (above 12 the criterion of 55 per cent of the Member States would not be met) if none of the other six most populous countries joins it. On the other hand, in this situation it is possible to form a blocking coalition if it includes the United Kingdom, France, Italy or Germany. It would have to be, however, between 10 and 12 members, or 8 in the case of Berlin. In practice, therefore, it is rather unlikely that a blocking coalition comprising no more than 13 Member States would be formed, if it is to include only one of the six most populous Member States. At the same time, it is extremely rare for two of the six most populous Member States to be outvoted by qualified majority when proceeding on legislative acts.

Further differences can also be found in the ability of the individual countries to form a strict minimum blocking coalition ${ }^{\mathrm{VIII}}$ with a small number of members, as presented in Table 8.

Table 8: the ability of the EU Member States to form strict minimum blocking coalitions with a small number of members under the double majority system

\begin{tabular}{|c|c|c|c|c|c|}
\hline \multirow[b]{2}{*}{$\begin{array}{l}\text { No. of } \\
\text { coalition } \\
\text { members }\end{array}$} & \multicolumn{5}{|c|}{$\begin{array}{l}\text { No. of possible coalition combinations for selected EU Member } \\
\text { States }\end{array}$} \\
\hline & Germany & France & Poland & Portugal & Luxembourg \\
\hline 4 & 215 & 168 & 90 & 14 & 10 \\
\hline 5 & 415 & 280 & 269 & 120 & 6 \\
\hline 6 & 1772 & 1020 & 654 & 632 & 74 \\
\hline 7 & 5195 & 3932 & 2366 & 2884 & 548 \\
\hline
\end{tabular}

Source: Own calculations. 
It is clear that in terms of the number of combinations of strict minimum blocking coalitions that can be formed by a member of the Council, with between four and seven members, Germany is better off than the other Member States, including France, second in terms of population. On the other hand, for countries with populations equal to Austria or smaller, the ability to form blocking coalitions composed of four or five members is only illusory as it requires the support of at least two or three of the six most populous countries, especially Germany. In practice, for qualified majority voting in the Council, the situation in which three of the six most populous countries are outvoted never happens. There are very rare cases when a decision is passed despite opposition from two of the six most populous Member States (Kleinowski 2012: 42-43). This suggests that the influence of the most populous members of the Council on decision-making is greater than would result from their formal voting power, and that a joint position of the majority of these countries determines the framework in which it is possible to reach an agreement. When the European Commission proposes an initiative that is supported by the majority of the Member States, including 4-5 of those with the largest populations, it is rather unlikely that the decision will be blocked in the Council - provided that there is a need to achieve a qualified majority of votes.

\section{Consistency}

In order to answer the question about the consistency of the systems analysed, we shall calculate the diversity of distribution using the average absolute deviation of the ratios of voting power to the square root of population of the individual players from the value of this ratio equalling 1 (full proportionality). We shall use the following formula:

$$
D=\frac{\sum_{i=1}^{n}\left|x_{i}-1\right|}{N}
$$

where:

$x_{i}$-ratio of voting power to the square root of population of the individual player $i$

$N-$ the total number of the players

The greater the value of $D$, the greater the average absolute deviation of the ratio of voting power to the square root of population of all the players. This shows how big, on 
average, the disproportion is between the voting power of a representative of a community in a council, and the square root of the population of the inhabitants or citizens he/she represents, and thus indicates how much on average the voting power of an inhabitant or player (country, Land) deviates in absolute terms from the vote weighting system in which the voting power of all inhabitants is equal (when all the prerequisites listed at the beginning of the article are met).

For the Bundesrat system $D=0.1834$, for the Nice system $D=0.1305$, and for the double majority system $\mathrm{D}=0.27$. As the average is sensitive to extreme values of the examined data set - as is the case when determining D for the vote weighting systems discussed in this article - we need to calculate its value excluding 15 per cent corresponding to the elements (statistical units) of the general population with extreme values. In this case, for the Bundesrat system $D_{-15 \%}=0.1578$, for the Nice system $D_{-15 \%}=0.1083$, and for the double majority system $\mathrm{D}_{-15 \%}=0.1849$.

As we can see, the value of $\mathrm{D}$ for the Nice system is significantly lower than for the others, both including and excluding the 15 per cent. This means that the absolute deviation of the ratio of voting power to the square root of the population of all the players is smaller. In other words, the formal voting power of countries in the Nice system is more proportional to the square root of their population than it is in the Bundesrat system and the double majority system.

\section{Conclusions}

In the German model of federalism, the division of powers between the federal state and the Länder, and the existing institutional solutions, make it necessary to constantly seek consensus as otherwise it would be very difficult to pass legislation. The Bundesrat is the cornerstone of the cooperative model. At the same time, the way votes are weighted in this institution considerably boosts the role of smaller Länder in the decision-making process. On the other hand, however, there is considerable risk of falling into the joint-decision trap (Scharpf 1988).

It could be argued that the European Union is clearly a much more complicated body than Germany, so some control is necessary to balance the influence of smaller member states. As a consequence, the increased efficiency of the decision-making process in the EU 
was recognised as a priority in the Treaty of Lisbon, which resulted in the abandonment of the Nice voting system, and in a significant increase in the scope of cases where decisions in the Council are adopted by a qualified majority (Miller and Taylor, 2008: 79-85).

The double majority voting system in the Council, introduced by the Treaty of Lisbon, lowers the decision-making threshold and consequently makes it easier to form a winning coalition. The criterion of population favours large countries, giving them the power to block decisions they deem unfavourable; this even creates situations in which such decisions are simply impossible. In this system, smaller countries help larger ones to block decisions in exchange for specific benefits. Medium countries, in turn, find it difficult to form a blocking coalition without the support of large countries because of the small populations of the coalition's members. As a result, this could be moving the political system of the European Union away from the model of cooperative federalism.

In communities such as federations granting certain favours to smaller members is admissible, as is the case in the Bundesrat. It is commonplace that the smaller members of the federation are privileged: the vote of a citizen of a smaller state in the federation has greater weight than the vote of a citizen of a larger state. Voting systems are based on a compromise between the equality of states and the equality of citizens. Our analysis has shown that the voting system applied in the Bundesrat and the Nice system reflect this compromise. The smaller elements of the federation in the first case and the smaller Member States in the second case had relatively greater power compared to their populations.

The Nice system and the voting system in the Bundesrat are not different in qualitative terms. The voting system in the Bundesrat has not raised any concerns, probably because Germans treat themselves as a demos, a political community understood as the common good, ruled by solidarity. Consequently, Germany introduced voting solutions in which less populous constituents of the federation receive preferential treatment. The European Union is not treated in this way by its citizens in view of the absence of collective identity and a European demos.

The institutional reform introduced by the Treaty of Lisbon affects the legitimacy of the EU political system. The aim was to compensate for the weakness of input legitimacy and to reduce the deficit of democracy in the $\mathrm{EU}^{\mathrm{IX}}$ by increasing the EU's problem-solving capacity. As Sharman (2008: 6-7) writes, "both forms of legitimacy express public 
assessment of the worth of an institution, but input legitimacy is a matter of the design of the institution, while output legitimacy must be earned by the institution's performance". The double majority voting system allows for a faster decision-making process in the Council, and for reaching an agreement in inter-institutional negotiations since, in the case of most countries, it considerably hinders the construction of a blocking coalition. It makes possible to adopt decisions which are not supported by a relatively large number of Council members. The field of possible compromise is determined to an even greater extent by the consistent position of the majority of the six largest EU Member States. Striving to increase the effectiveness of the decision-making process by reducing the readiness to seek compromise may however adversely affect the level of identification of citizens of the Member States with the EU.

A political community is indispensable for discipline, imposed by democratic rule of the majority, to be accepted. At the state level, the minority accepts the decision of the majority because both the majority and the minority are parts of the same nation. In federal systems, less populous constituent states usually receive preferential treatment, to a certain extent, in terms of representation. At the EU level this is no longer the case after the change of the voting system. The system introduced in the Treaty of Lisbon breaks with the idea of voting principles advantageous for less populous states, which have existed in the EU for half of century.

\footnotetext{
* Jacek Czaputowicz is a Professor and Head of Methodology of European Studies unit at the Institute of European Studies, Faculty of Political Sciences and International Studies, University of Warsaw. He writes on different aspects of European integration, international security and theories of international relations.

Marcin Kleinowski is an Assistant Professor in the Faculty of Political Sciences and International Studies, Nicolaus Copernicus University in Torun. His main research interests are focused on the process of European integration with particular emphasis on decision-making in the European Union.

The values of the mathematical voting power indexes were calculated using the POWERGEN 3.0 program as part of research project No. UMO-2016/23/D/HS5/00408 (SONATA 12 competition) 'The Impact of Brexit and Unconditional Introduction of the "Double Majority" Voting System on Decision-Making in the Council of the European Union', organized by the National Science Centre (in Poland).

I A similar position is presented by, for example, Poirier and Saunders (2015).

II Own calculation performed using the programme POWERGEN 3.0 by Marcin Kleinowski.

III Treaty on European Union (consolidated version), Article 16(3). Treaty on the Functioning of the European Union (consolidated version), Article 238(2).

IV For more see: Czaputowicz (2014).

v Own calculations on the basis of Council Decision (EU, Euratom) 2015/2393 (2015) and Eurostat (2015).

VI An analysis of European Union legislative proposals withdrawn by the European Commission or rejected by the Member States between 2013 and 2015, which required achieving a qualified majority in the Council of the EU, shows that the annual number of such proposals can be estimated at between a few and a dozen or so cases, of which only some were opposed to by most of the Member States. Most cases when an initiative of the European Commission gave rise to opposition of a large number of Council members, concerned non-
} 
legislative proposals related to admitting genetically modified food to the market or the application of certain substances, especially in the food industry (Pollack \& Shaffer, pp. 144-164; Kleinowski, 2012, pp. 33-34).

VII Treaty on European Union, Article 16(3); Treaty on the Functioning of the European Union, Article 238(2).

VIII A winning or blocking coalition is referred to as a strict minimum coalition when none among the subcoalitions have equal voting power, so they cannot ensure the adoption of a decision or block it, respectively.

IX More on the definition of input and output legitimacy, cf. Easton (1965), Schmidt (2010).

\section{References}

- Albert Max, 2003, 'The Voting Power Approach: Measurement without Theory', European Union Politics, IV(3): 351-366.

- Albert Max, 2004, 'The voting Power Approach: Unresolved Ambiguities', European Union Politics, $\mathrm{V}(1): 139-146$.

- Baldwin Richard and Widgrén Mika, 2004, 'Winners and losers under various dual-majority voting rules for the EU's Council of Ministers', CEPS Policy Brief, 50, 1-35.

- Banzhaf John F., 1965, 'Weighted voting does not work: A mathematical analysis', Rutgers Law Review, XIX(2): 317-343.

- $\quad$ Barry Brian, 1980, 'Is It Better to be Powerful or Lucky, part 2', Political Studies, XXVIII(3): 317-343.

- Burgess Michael, 2000, Federalism and European Union. The Building of Europe, 1950-2000, Routledge, London and New York.

- Conway Gerard, 2011, 'Recovering a separation of powers in the European Union', European Law Journal, XVII(3): 308-322.

- $\quad$ Council Decision (EU, Euratom) 2015/2393 of 8 December 2015 amending the Council's Rules of Procedure, OJ 2015, L 332.

- Czaputowicz Jacek, 2014, 'Demokracja a suwerenność w Unii Europejskiej' (Democracy and Sovereignty in the European Union), in Wojtaszczyk Konstanty, Mizerska-Wrotkowska Małgorzata, Jakubowski Wojciech (eds), Polska w procesie integracji europejskiej: dekada dośmiadczeń (2004-2014) (Poland in the Process of European Integration: A Decade of Experience), Wydział Dziennikarstwa i Nauk Politycznych, Uniwersytet Warszawski, Warszawa.

- $\quad$ von Dosenrode Søren, 2016, 'Federalism', in von Dosenrode Søren (ed), Approaching the European Federation?, Routledge, London, New York.

- $\quad$ Easton David, 1965, A Systems Analysis of Political Life, John Wiley, New York.

- $\quad$ Eurostat, 2015, Population without the citizenship of the reporting country (data for 2014), Retrieved from http://ec.europa.eu/eurostat/tgm/web/ download/Eurostat Table tps00157FlagDesc 56058361b81d-43d6-9cff-8291ad3eec6e.xls.

- $\quad$ Fabbrini Sergio, 2012, 'The democratic governance of the Euro, Comments by Sergio Fabbrini', RSCAS Policy Papers, 08: 27-31.

- Felsenthal Dan S. and Machover Moshé, 1998, The measurement of voting power. Theory and practice, problems and paradoxes, Edward Elgar, Cheltenham, Northampton.

- Felsenthal Dan S. and Machover Moshé, 2004, 'Analysis of QM rules in the draft constitution for Europe proposed by the European Convention', Social Choice and Welfare, XXIII(1): 1-20.

- Foster Nigel G. and Sule Satish, 2010, German Legal System and Laws (4th ed.), Oxford University Press, New York.

- Garret Geoffrey and Tsebelis George, 1999a, 'Why Resist the Temptation to Apply Power Indices to the European Union', Journal of Theoretical Politics, XI(3): 291-308.

- Garret Geoffrey and Tsebelis George, 1999b, 'More Reasons to Resist the Temptation of Power Indices in the European Union', Journal of Theoretical Politics, XI(3): 331-338.

- Gunlicks Arthur, 2003, The Länder and German federalism, Manchester University Press, Manchester.

- $\quad$ Kirsch Werner, 2007, 'On Penrose's square-root law and beyond', Homo Oeconomicus, XXIV(3-4): 357380. 
- Kleinowski Marcin, 2012, 'Consensual Negotiations or Voting - Contestation of Legal Acts in the Council', Studia Europejskie, LXIV(4): 27-50.

- Lenaerts Koen, 1991, 'Some reflections on the separation of powers in the European Community', Common Market Law Review, XXVIII(1): 11-35.

- Lindner Ines, 2008, 'The power of a collectivity to act in weighted voting games with many small voters', Social Choice and Welfare, XXX(4): 581-601.

- Miller Vaughne and Taylor Claire, 2008, 'The Treaty of Lisbon: Amendments to the Treaty on European Union', House of Commons Research Paper, 09: 1-85.

- $\quad$ Neyer Jürgen, 2010, 'Europe's justice deficit: Justification and legitimacy in the EU' in Neyer Jürgen and Wiener Antje (eds), Political theory of the European Union, Oxford University Press, Oxford, 169-186.

- $\quad$ Penrose Lionel S., 1946, 'The elementary statistics of majority voting', Journal of the Royal Statistical Society, 109: 53-57.

- Plechanovová Bela, 2004, 'Draft Constitution and the decision-making rule for the Council of Ministers of the EU - Looking for alternative solution', European Integration online Papers (EIoP), VIII(12): 1-13.

- Pollack, Mark A. and Shaffer Gregory C., 2008, 'Risk regulation, GMOs and the limits of deliberation' in Naurin Daniel \& Hellen Wallace (eds), Unveiling the Council of the European Union. Games governments play in Brussels, Palgrave Macmillan, Basingstoke, 144-164.

- $\quad$ Protocol (No 36) on Transitional Provisions, OJ 2012, C 326.

- Regulation (EU) No 1260/2013 of the European Parliament and of the Council of 20 November 2013 on European demographic statistics, OJ 2012, L 330.

- $\quad$ Roberts Geoffrey K., 2009, German politics today (2nd ed.), Oxford University Press, Manchester.

- Rudzio Wolfgang, 2015, Das politische System der Bundesrepublik Deutschland (9 Auflage), Springer VS, Wiesbaden.

- $\quad$ Scharpf Fritz W., 1988, 'The Joint-Decision Trap: Lessons from German Federalism and European Integration', Public Administration, LXVI(3): 239-278.

- $\quad$ Schmidt Manfred G, 2016, Das politische System der Bundesrepublik Deutschland, C.H. Beck, München.

- Schmidt Vivien, 2013, 'Democracy and Legitimacy in the European Union Revisited: Input, Output and 'Throughput', Political Studies, LXI(1): 2-22.

- Schönberger Christoph, 2009, 'Lisbon in Karlsruhe: Maastricht's epigones at see', German Law Journal, $\mathrm{X}(08):$ 1201-1218.

- Schulz Martin, 2014, Skerepowany olbrzym. Ostania szansa Europy, Muza SA, Warszawa, originally published as Schulz Martin, 2013, Der gefesselte Riese. Europas letate Chance, Rowohlt Verlag, Berlin.

- Scientist for a Democratic Europe, 2004, Letter to the governments of the EU member states, Retrieved from http://www.esi2.us.es/ mbilbao/pdffiles/letter.pdf.

- $\quad$ Sharman Campbell, 'Political Legitimacy for an Appointed Senate', IRPP Choices, XIV(11): 2-24.

- Treaty on European Union (consolidated version), OJ 2012, C 326.

- $\quad$ Treaty on the Functioning of the European Union (consolidated version), OJ 2012, C 326.

- Ziller Jacques, 2008, 'Separation of powers in the European Union's intertwined system of government - A treaty based analysis for the use of political scientists and constitutional lawyers', Il Politico, LXXIII(3): 133-179. 